\title{
Life Cycle Assessment and Life Cycle Cost of Waste Management-Plastic Cable Waste
}

\author{
Mats Zackrisson, Christina Jönsson, Elisabeth Olsson \\ Energy and Environment Group, Department of Materials, Swerea IVF AB, Mölndal, Sweden \\ Email: mats.zackrisson@swerea.se
}

Received 23 January 2014; revised 20 February 2014; accepted 27 February 2014

Copyright (C) 2014 by authors and Scientific Research Publishing Inc.

This work is licensed under the Creative Commons Attribution International License (CC BY). http://creativecommons.org/licenses/by/4.0/

(c) (i) Open Access

\begin{abstract}
The main driver for recycling cable wastes is the high value of the conducting metal, while the plastic with its lower value is often neglected. New improved cable plastic recycling routes can provide both economic and environmental incentive to cable producers for moving up the "cable plastic waste ladder". Cradle-to-gate life cycle assessment, LCA, of the waste management of the cable scrap is suggested and explained as a method to analyze the pros and cons of different cable scrap recycling options at hand. Economic and environmental data about different recycling processes and other relevant processes and materials are given. Cable producers can use this data and method to assess the way they deal with the cable plastic waste today and compare it with available alternatives and thus illuminate the improvement potential of recycling cable plastic waste both in an environmental and in an economic sense. The methodology applied consists of: cradle-to-gate LCA for waste material to a recycled material (recyclate); quantifying the climate impact for each step on the waste ladder for the specific waste material; the use of economic and climate impact data in parallel; climate impact presented as a span to portray the insecurities related to which material the waste will replace; and possibilities for do-it-yourself calculations. Potentially, the methodology can be useful also for other waste materials in the future.
\end{abstract}

\section{Keywords}

Cable Recycling, Life Cycle Assessment, LCA, Life Cycle Cost, LCC, Economic Analysis, Climate Impact, Waste Recycling

\section{Introduction}

The main driver for recycling cables is the high value of the conducting metal (usually copper or aluminium), while the plastic with its lower value is often neglected. On the other hand, if it is not for the metal, the whole 
waste cable may be neglected, as it is often experienced with optical waste cables today [1]. This paper aims to provide primarily cable producers with a methodology to assess the way they deal with the cable plastic waste today and compare it with available alternatives and thus facilitate realizing the improvement potential of recycling cable plastic waste. The hypothesis is that it is possible to create a transparent methodology that provides additional insights and incentives of the value of recycling the plastic parts in addition to the metal core of the cable. Through using the methodology provided, the reader or user will be able to show the climate effects of improving the cable waste recycling (compared to how it is done today) and also to show the economic, technical and management implications of such improvements. The methodology as such can also be applicable to other waste materials.

The situation with small or negligible profit margins is similar for many other waste materials, for example textiles and construction waste [2]. It is therefore important to include economic data when analyzing waste recycling options. The simple knowledge that recycling a particular waste would lead to reduced environmental impact will not automatically lead to that it will be done; it will have to be economically beneficial (or enforced by law) otherwise it will not happen.

This paper and underlying report [3] have been compiled within the scope of the Wire and Cable project which is managed by the Swedish research institute Swerea IVF and financed by Vinnova, a Swedish governmental funding agency, and participating companies. The following cable manufacturers, polymer manufacturers, cable users and recycling companies are members of the project running from 2010 to 2013: Borealis AB, Draka Kabel Sverige AB, Ineos ChlorVinyls, Nexans Sweden AB, ABB AB, Stena Metall AB, Volvo Lastvagnar AB, Volvo Personvagnar AB and Ericsson AB. The main objective of the Cable project is to facilitate increased recycling of cable plastics. As from 2014, the Wire and Cable project will continue with many of the old members and some new ones.

\section{Method}

The methodology described and applied below consists of: cradle-to-gate LCA, life cycle assessment, for waste material to recyclate; quantifying the climate impact for each step on the waste ladder for the specific waste material; the reporting of economic and climate impact data in parallel; presentation of the climate impact as a span to portray the insecurities related to which material the waste will replace; and possibilities for do-it-yourself calculations. It has been developed in cooperation with the cable industry and used by them. It follows guidance about LCA of waste management issued by EUs Joint Research Centre [4], which in turn builds on the International Organization for Standardization (ISO) 14044 standard [5] for LCA and the International Reference Life Cycle Data System Handbook [6]. Similar methodology may be useful also for waste categories other than cable waste.

\subsection{Life Cycle Assessment in General}

LCA according to ISO 14044 [5] consist of four stages: scooping, inventory, environmental impact assessment and interpretation. All stages except the one for environmental impact assessment are considered obligatory. The stages are often repeated in an iterative way that gradually refines the assessment. None of the stages are unique to the LCA methodology. What makes LCA unique is that all (or as many as possible/relevant) life cycle phases of the analyzed object are included from raw material extraction to the product's end-of-life [7]. The life cycle phases are often referred to as raw material production, (own) manufacturing, use and end-of-life [8], see Figure 1.

When all life cycle phases are included in an LCA study, it is referred to as a cradle-to-grave study [4]. Studies that only include data about raw material production and own manufacturing are referred to as cradle-togate studies. Such cradle-to-gate LCA studies exist for most commodities like different steels, plastics etc.

\subsection{Proposed LCA Application}

Life cycle assessment of waste materials or waste management, though very common, has no special name in literature. A complete product life cycle as depicted in Figure 1 is rarely involved [4]. Instead, focus lies on recycling processes after the use phase or directly after the manufacturing processes as shown in Figure 2. Also production of virgin materials is included in order to account for that material recycling avoids primary or virgin material production. As can be seen, LCA of waste materials span over two adjacent product life cycles. 


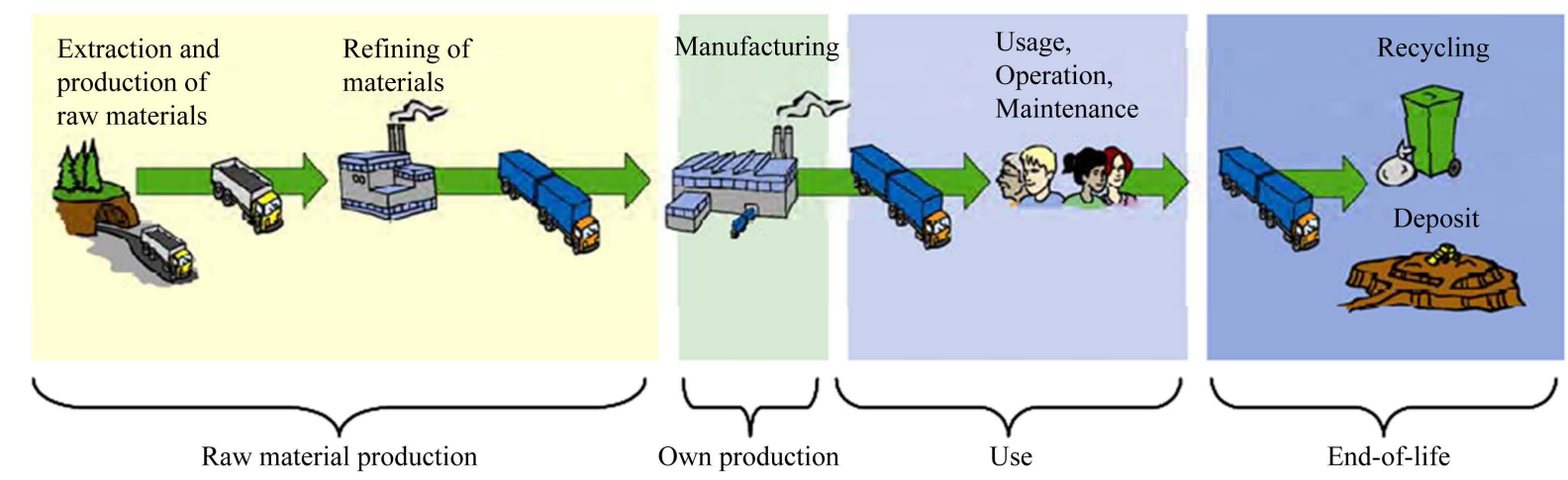

Figure 1. Life cycle assessment.

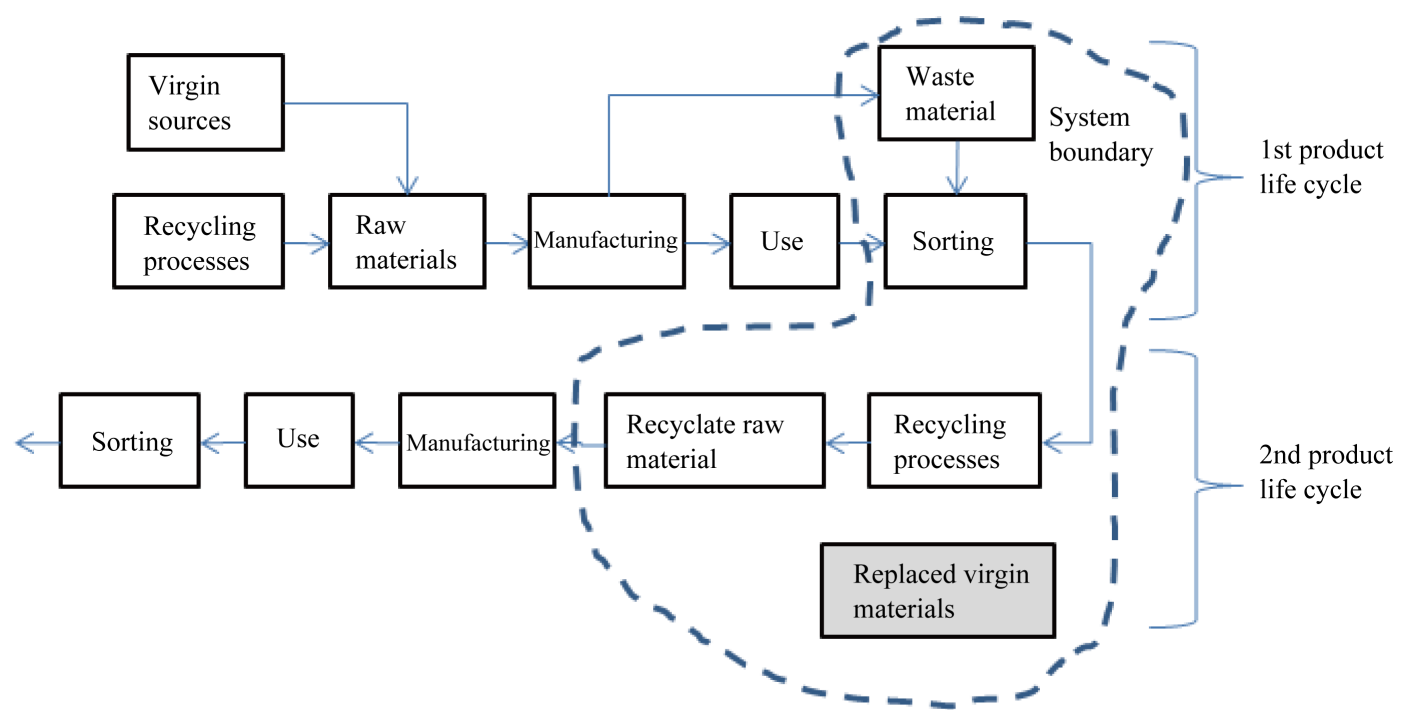

Figure 2. System boundary of LCA recycling study.

Often these product life cycles are for different products, i.e. cable plastic waste is rarely used to make new cables but rather to make other products. This is referred to as open-loop recycling, or, since it often entails a loss of valuable material properties, down-cycling [4].

Another way of seeing it is that the product or service under investigation is not the cable but rather the waste management of the cable, where the waste material is the input and the produced recyclate is the output, see Figure 3. In such a perspective the study could be compared to a cradle-to-gate LCA for a commodity from virgin origin, see Figure 1.

Focusing on the service required to manage the waste in the best way makes it natural to present the results per unit of cable plastic waste or per unit of cable waste, i.e. sometimes including the conducting metal. In LCA language these are the functional units used. A correct generic name of the functional unit would be waste management per unit of waste material. The starting point is the waste. Something has to be done about it; it cannot just be left in a pile; it has to be managed.

The waste ladder in Figure 4 portrays the waste management options generally available. It is considered in general to be environmentally preferable to be as high on the ladder as possible. The waste ladder or waste hierarchy is encouraged by the European Union (EU) Waste Framework Directive [9], though departing from the hierarchy could be justified for, among other, reasons of technical feasibility and economic viability. In this paper, the climate impact associated with each step is calculated for the management of plastic waste from cables in order to further stimulate companies to move up the waste ladder.

The choice of system boundary and functional unit(s) means that there is no need to include the actual cable manufacturing or the use of the cables in the calculations. This is of course very advantageous since it limits 


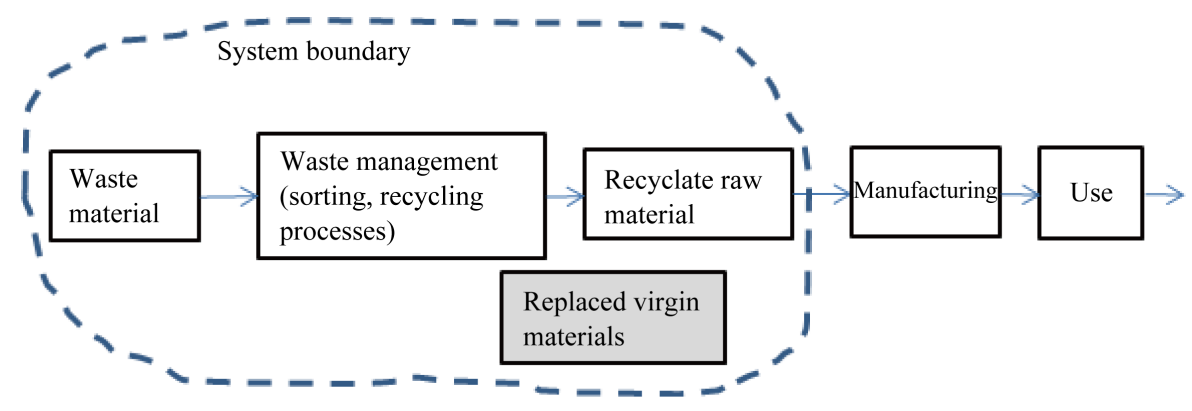

Figure 3. System boundary of cradle-to-gate waste management LCA.

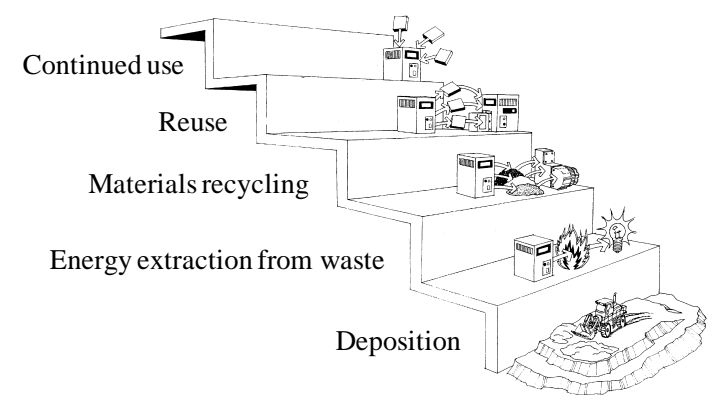

Figure 4. The waste ladder.

drastically the amount of data needed for the analysis. However, such upstream activities may only be excluded if they are not affected by any of the investigated waste management options [4]. For example, if internal recycling of production cable waste is one option, the quality must be the same (as the normally used material) so that the cable manufacturing or use is not affected.

Cable producers and recycling companies have provided site-specific data for this paper and underlying reports [3] [10]. Sometimes averages from several companies with the same process are provided. For certain processes, e.g. transports and primary metal manufacturing, generic instead of specific process data is presented. This generic data stem from public LCA databases and represent in general European or global averages. Data has mainly been drawn from the database Ecoinvent 2.0 [11].

The studied system is expanded to include avoided processes and the subsequent avoided environmental impacts when the recycled materials replace virgin materials. Avoided processes are shaded grey in the figures above. The choice of avoided process is very critical when system expansion is used [4] [7]. For example, since recycled copper can replace virgin copper, the environmental burdens for virgin copper manufacturing are subtracted from the studied system. Similarly, plastic recyclate can replace virgin plastic in some applications. However, it is rare that plastic recyclate can actually replace virgin plastic fully, more often some form of loss of material properties occur and this makes it difficult to define the replaced material. ISO 14044 [5] contains guidance concerning deciding the avoided or replaced material. The replacement should be based on, in priority order:

- Physical properties (e.g. mass or energy content);

- Economic value (e.g. market value of the scrap material or recycled material in relation to market value of primary material).

In order to follow ISO 14044 and also to somewhat capture that recycling almost always entail down-cycling, i.e., the recyclate has less good properties than the virgin resource, this paper presents two different scenarios:

- 1 to 1 . In the 1 to 1 scenario $1 \mathrm{~kg}$ of recyclate is replacing $1 \mathrm{~kg}$ of the virgin material; e.g. $1 \mathrm{~kg}$ of recyclate polyvinyl chloride (PVC) compound replaces $1 \mathrm{~kg}$ of virgin PVC compound. Thus, the environmental burdens associated with manufacturing of virgin PVC compound is subtracted from the studied system (the cradle-to-gate waste management LCA) on a 1 to 1 basis.

- Market based. In the market based scenario, it is assumed that the loss of quality of the recyclate is proportional to the relation between the price paid for the recyclate and the price paid for the virgin material. Due to the loss of quality the recyclate cannot replace virgin material of the same type. What it can replace we do 
not know, so we assume, that the "environmental burdens saved" are proportional to the loss of quality which we assume is proportional to the difference in price. For example, if PVC recyclate is paid at 88 euro $(€)$ per tonne and the price of virgin PVC is $1320 €$ per tonne, 88/1320 $=0.07=7 \%$ of the environmental burdens of virgin PVC manufacturing are subtracted from the studied system to account for the material that the recyclate is replacing.

Normally in LCA, at least five impact categories are used: climate change; acidification; ozone depletion; photochemical smog and eutrophication. In this paper, only climate change results are presented, in carbon dioxide equivalents $\left(\mathrm{CO}_{2} \mathrm{eq}\right)$. Since $\mathrm{CO}_{2} \mathrm{eq}$ is a good indicator for energy related environmental impact and most data sets related to cable waste management is dominated by energy use it has been shown [3] that $\mathrm{CO}_{2} \mathrm{eq}$ is a good indicator for the environmental impact of cable waste recycling. For calculation of non $\mathrm{CO}_{2}$ gases to $\mathrm{CO}_{2}$ eq the latest characterization factors from the Intergovernmental Panel on Climate Change (IPCC) [12] have been used.

\subsection{Life Cycle Cost Methodology}

Life cycle cost (LCC) [13] as applied in this paper refers to all costs and incomes of a particular waste incurred to the owner of the waste. For example, cost of transport (internal and external), waste processing costs, disposal costs and price of recyclates. The LCC thus shows (the waste owner) the profitability of each studied waste management option. The collection of data and identification of data required were achieved in parallel with the LCA.

\section{Results}

In order to calculate the benefits of different recycling routes, monetary and climate change data about the involved recycling processes, transports and avoided (replaced) products have been collected. The units are euro $(€)$ and gram carbon dioxide equivalents $\left(\mathrm{CO}_{2} \mathrm{eq}\right)$. In order to facilitate calculations and comparisons, data have been assembled in one sheet, see Table 1 . The idea with the sheet is to facilitate finding and marking data that is relevant for a unique comparison, sum it up and arrive at the results.

\subsection{Reduction of Climate Impacts by Moving up the Cable Plastic Waste Ladder}

The potential gains of improving the cable plastic waste recycling by moving up the "waste ladder" are illustrated in Figure 5. All values are per kg of plastic waste. Note that the potential gains by the associated metal recycling are not shown in this figure.

The spans given reflect the different scenarios-market based or "1 to 1"-and the different polymers involved. Apart from the landfill figure, all figures are related to avoided products/processes, in the green part of Table 1. It is the replaced or avoided product that gives the largest climate impact contribution. Recycling processes and transports give only minor climate impacts and are therefore not included in the Figure 5 calculations. All figures are absolute, i.e. relative to zero.

Avoiding plastic (and metal) cable waste completely is of course the primary target of all cable producers, but not always possible. On the other hand, moving one or two steps up the ladder is not only possible but also to a degree driven by legislation limiting landfill and energy recycling. Moving one step up the waste ladder would mean avoiding around $0.5 \mathrm{~kg} \mathrm{CO}$ eq/kg plastic. Consumption of plastic compounds by the European cable industry in 2012 was 1.23 million tonnes [14]. Plastic waste from cable manufacturers are around $5 \%$ of their total use of plastic [3]. If the industry as a whole can move one step up the waste ladder about 1,230,000,000 $\times 0.05 \times$ $0.5 \mathrm{~kg} \mathrm{CO} 2 \mathrm{eq} / \mathrm{kg}=30,750$ tonnes of $\mathrm{CO}_{2}$ eq can be avoided annually.

\subsection{Life Cycle Cost or Economic Feasibility}

Recycling processes and transports may only have minor climate impacts, but they are very important from an economical point of view. Therefore indicative price information is given in Table 1, in order to investigate the economical feasibility of different recycling options. Results from the LCC show that moving one step up at the top of the waste ladder can increase profits by almost $2 €$ per kg plastic, see Table 1 . At the bottom of the plastic waste ladder there is a landfill cost of $0.12 € / \mathrm{kg}$ and additional transportation costs. 
Table 1. Hot milling of PVC scrap compared to external recycling.

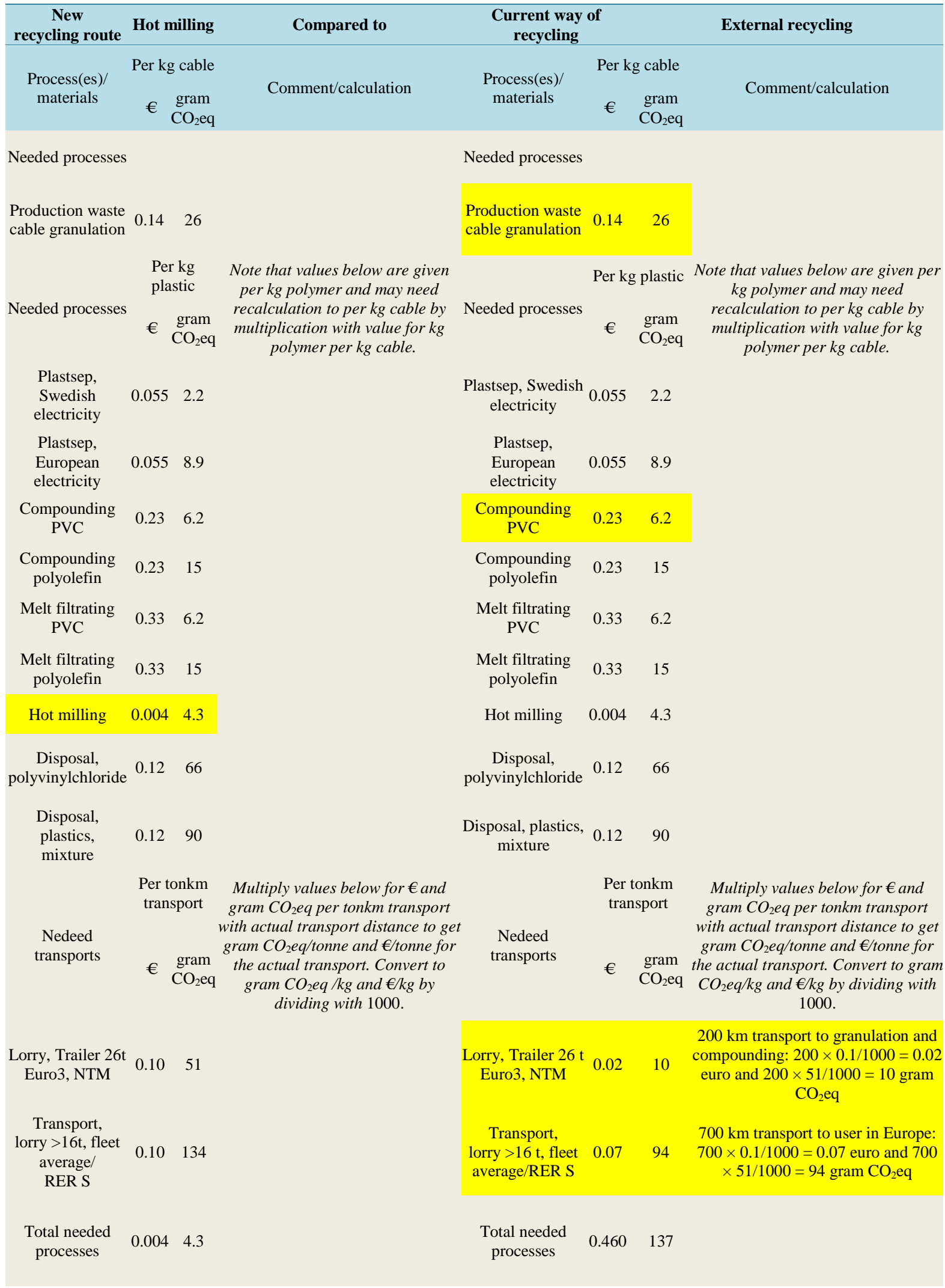




\section{Continued}

\begin{tabular}{|c|c|c|c|c|c|c|c|c|c|}
\hline \multirow[b]{2}{*}{$\begin{array}{l}\text { Avoided } \\
\text { processes }\end{array}$} & \multicolumn{3}{|c|}{ Per kg material } & \multirow{2}{*}{$\begin{array}{c}\text { Note that values below are } \\
\text { given per } \mathrm{kg} \text { material and } \\
\text { may need recalculation to } \\
\text { per } \mathrm{kg} \text { cable by multiplication } \\
\text { with value for } \mathrm{kg} \text { material } \\
\text { per } \mathrm{kg} \text { cable. }\end{array}$} & \multirow[b]{2}{*}{$\begin{array}{l}\text { Avoided } \\
\text { processes }\end{array}$} & \multicolumn{3}{|c|}{ Per kg material } & \multirow{2}{*}{$\begin{array}{c}\text { Note that values below are } \\
\text { given per } \mathrm{kg} \text { material and } \\
\text { may need recalculation to per } \\
\mathrm{kg} \text { cable by multiplication } \\
\text { with value for } \mathrm{kg} \text { material per } \\
\text { kg cable. }\end{array}$} \\
\hline & $€$ & $\begin{array}{c}\text { Market } \\
\text { gram }\end{array}$ & $\begin{array}{l}1 \text { to } 1 \\
\mathrm{CO}_{2} \mathrm{eq}\end{array}$ & & & $€$ & $\begin{array}{c}\text { Market } \\
\text { gram }\end{array}$ & $\begin{array}{l}1 \text { to } 1 \\
\mathrm{CO}_{2} \mathrm{eq}\end{array}$ & \\
\hline $\begin{array}{c}\text { Copper, } \\
\text { primary, at } \\
\text { refinery/GLO S }\end{array}$ & -5.5 & -3160 & -3160 & & $\begin{array}{c}\text { Copper, } \\
\text { primary, at } \\
\text { refinery/GLO S }\end{array}$ & -5.5 & -3160 & -3160 & \\
\hline $\begin{array}{l}\text { Copper } \\
\text { granulate }\end{array}$ & -5.3 & -3065 & -3160 & & $\begin{array}{l}\text { Copper } \\
\text { granulate }\end{array}$ & -5.3 & -3065 & -3160 & \\
\hline Copper fluff & -4.6 & -2686 & -3160 & & Copper fluff & -4.6 & -2686 & -3160 & \\
\hline $\begin{array}{l}\text { Aluminium, } \\
\text { primary, at } \\
\text { plant/RER S }\end{array}$ & -1.6 & $-12,200$ & $-12,200$ & & $\begin{array}{l}\text { Aluminium, } \\
\text { primary, at } \\
\text { plant/RER S }\end{array}$ & -1.6 & $\begin{array}{c}-12,20 \\
0\end{array}$ & $-12,200$ & \\
\hline $\begin{array}{l}\text { Aluminium } \\
\text { granulate }\end{array}$ & -1.5 & $-11,346$ & $-12,200$ & & $\begin{array}{l}\text { Aluminium } \\
\text { granulate }\end{array}$ & -1.5 & $\begin{array}{c}-11,34 \\
6\end{array}$ & $-12,200$ & \\
\hline $\begin{array}{l}\text { Aluminium } \\
\text { fluff }\end{array}$ & -1.3 & -10370 & $-12,200$ & & $\begin{array}{l}\text { Aluminium } \\
\text { fluff }\end{array}$ & -1.3 & $\begin{array}{c}-10,37 \\
0\end{array}$ & $-12,200$ & \\
\hline $\begin{array}{l}\text { Heavy fuel oil, } \\
\text { at regional } \\
\text { storage/RER S }\end{array}$ & -1.1 & -455 & -455 & & $\begin{array}{l}\text { Heavy fuel oil, } \\
\text { at regional } \\
\text { storage/RER S }\end{array}$ & -1.1 & -455 & -455 & \\
\hline HFFR as oil & 0.058 & 9 & -166 & & $\begin{array}{l}\text { HFFR as oil } \\
\text { replacement }\end{array}$ & 0.058 & 9 & -166 & \\
\hline $\begin{array}{l}\text { Polyolefins } \\
\text { as oil } \\
\text { replacement }\end{array}$ & -0.022 & -9 & -477 & & $\begin{array}{l}\text { Polyolefins as } \\
\text { oil replacement }\end{array}$ & -0.022 & -9 & -477 & \\
\hline $\begin{array}{l}\text { PVC } \\
\text { compound for } \\
\text { cable I }\end{array}$ & -1.3 & -1500 & -1500 & & $\begin{array}{l}\text { PVC } \\
\text { compound for } \\
\text { cable I }\end{array}$ & -1.3 & -1500 & -1500 & \\
\hline $\begin{array}{c}\text { PVC } \\
\text { recyclate I }\end{array}$ & -0.09 & -100 & -1500 & & $\begin{array}{c}\text { PVC } \\
\text { recyclate I }\end{array}$ & -0.09 & -100 & -1500 & \\
\hline $\begin{array}{l}\text { HFFR } \\
\text { compound for } \\
\text { cable }\end{array}$ & -2.0 & -1170 & -1170 & & $\begin{array}{l}\text { HFFR } \\
\text { compound for } \\
\text { cable }\end{array}$ & -2.0 & -1170 & -1170 & \\
\hline $\begin{array}{c}\text { HFFR } \\
\text { recyclate }\end{array}$ & -0.11 & -65 & -1170 & & $\begin{array}{l}\text { HFFR recyc- } \\
\text { late }\end{array}$ & -0.11 & -65 & -1170 & \\
\hline $\begin{array}{l}\text { Compounding } \\
\text { PVC }\end{array}$ & -0.23 & -6.2 & -6.2 & & $\begin{array}{l}\text { Compounding } \\
\text { PVC }\end{array}$ & -0.23 & -6.2 & -6.2 & \\
\hline $\begin{array}{c}\text { Compounding } \\
\text { polyolefin }\end{array}$ & -0.23 & -15 & -15 & & $\begin{array}{l}\text { Compounding } \\
\text { polyolefin }\end{array}$ & -0.23 & -15 & -15 & \\
\hline $\begin{array}{l}\text { Avoided } \\
\text { transports }\end{array}$ & Per to & on km tra & ansport & $\begin{array}{c}\text { Multiply values below for } € \\
\text { and gram } \mathrm{CO}_{2} \text { eq per tonkm } \\
\text { transport with actual } \\
\text { transport distance to get } \\
\text { gram } \mathrm{CO}_{2} \text { eq/tonne and } \\
\text { €/tonne for the actual } \\
\text { transport. Convert to gram } \\
\mathrm{CO}_{2} \text { eq } / \mathrm{kg} \text { and } € / \mathrm{kg} \text { by } \\
\text { dividing with } 1000 \text {. }\end{array}$ & $\begin{array}{l}\text { Avoided } \\
\text { transports }\end{array}$ & Per to & onkm tral & $\mathrm{CO}_{2} \mathrm{eq}$ & $\begin{array}{c}\text { Multiply values below for } € \\
\text { and gram } \mathrm{CO}_{2} \text { eq per tonkm } \\
\text { transport with actual } \\
\text { transport distance to get } \\
\text { gram } \mathrm{CO}_{2} \text { eq/tonne and } \\
€ / \text { tonne for the actual trans- } \\
\text { port. Convert to gram } \mathrm{CO}_{2} \text { eq } \\
/ \mathrm{kg} \text { and } € / \mathrm{kg} \text { by dividing with } \\
1000 \text {. }\end{array}$ \\
\hline $\begin{array}{c}\text { Lorry, Trailer } \\
\text { 26t Euro3, } \\
\text { NTM }\end{array}$ & -0.02 & -10 & -10 & $\begin{array}{l}200 \text { km transport from PVC } \\
\text { supplier avoided. }\end{array}$ & $\begin{array}{l}\text { Lorry, Trailer } \\
26 \text { t Euro3, } \\
\text { NTM }\end{array}$ & -0.10 & -51 & -51 & \\
\hline $\begin{array}{l}\text { Transport, } \\
\text { lorry }>16 t \text {, fleet } \\
\text { average/ } \\
\text { RER S }\end{array}$ & -0.10 & -134 & -134 & & $\begin{array}{c}\text { Transport, } \\
\text { lorry }>16 \mathrm{t} \text {, } \\
\text { fleet } \\
\text { average/RER S }\end{array}$ & -0.10 & -134 & -134 & \\
\hline & & $\mathrm{r}$ kg mate & erial & & & & r kg mate & erial & \\
\hline & $€$ & $\begin{array}{r}\text { Market } \\
\text { gram }\end{array}$ & $\begin{array}{l}1 \text { to } 1 \\
\mathrm{CO}_{2} \mathrm{eq}\end{array}$ & & & $€$ & $\begin{array}{c}\text { Market } \\
\text { gram }\end{array}$ & $\begin{array}{c}1 \text { to } 1 \\
\mathrm{CO}_{2} \mathrm{eq}\end{array}$ & \\
\hline $\begin{array}{l}\text { Total avoided } \\
\text { processes }\end{array}$ & -1.550 & -1516 & -1516 & & $\begin{array}{l}\text { Total avoided } \\
\text { processes }\end{array}$ & -0.09 & -100 & -1500 & \\
\hline $\begin{array}{c}\text { Total of needed } \\
\text { and avoided } \\
\text { processes }\end{array}$ & -1.546 & -1512 & -1512 & & $\begin{array}{c}\text { Total of needed } \\
\text { and avoided } \\
\text { processes }\end{array}$ & 0.370 & 37 & -1364 & \\
\hline
\end{tabular}




\section{Continued}

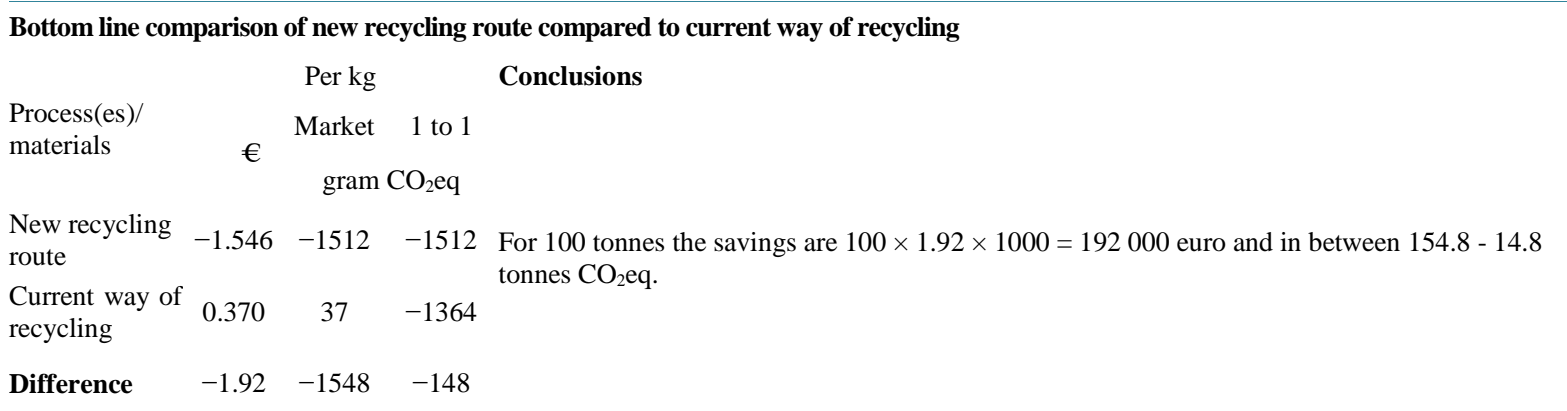

Notes to the calculation of the LCA comparison between Hot milling and External recycling in Figure 6 and Table 1. Boxes coloured yellow in table 1 apply! Hot milling, left columns: Hot milling costs $0.004 \mathrm{€} / \mathrm{kg}$ plastic and entails 4.3 gram $\mathrm{CO}_{2} \mathrm{eq} / \mathrm{kg}$ plastic emissions. Production of virgin PVC is avoided, thus $1.3 € / \mathrm{kg}$ plastic and 1500 gram $\mathrm{CO}_{2} \mathrm{eq} / \mathrm{kg}$ plastic is avoided. Compounding of PVC is avoided, thus $0.23 € / \mathrm{kg}$ plastic and 6.2 gram $\mathrm{CO}_{2} \mathrm{eq} / \mathrm{kg}$ plastic is avoided. Transport, $200 \mathrm{~km}$, of virgin PVC is avoided, thus $0.1 \times 200 / 1000=0.02 € / \mathrm{kg}$ plastic and $51 \times 200 / 1000=10$ gram CO $\mathrm{eq} /$ $\mathrm{kg}$ plastic is avoided. Since there is no down-cycling of the material (no loss of quality), the market perspective and the 1 to 1 perspective yield the same results! For Hot milling, the total of needed processes minus avoided processes is a gain of $1.546 € / \mathrm{kg}$ plastic and avoidance of 1512 gram $\mathrm{CO}_{2} \mathrm{eq} / \mathrm{kg}$ plastic. External recycling, right columns: Granulation of hardened lumps costs $0.14 € / \mathrm{kg}$ plastic and entails 26 gram CO emissions. Compounding the granulated PVC costs $0.23 € / \mathrm{kg}$ plastic and entails 6.2 gram $\mathrm{CO}_{2} \mathrm{eq} / \mathrm{kg}$ plastic emissions. Transport, $200 \mathrm{~km}$, of PVC lumps to granulation costs $0.1 \times 200 / 1000=0.02 € / \mathrm{kg}$ plastic and entails $51 \times 200 / 1000=10$ gram $\mathrm{CO}_{2} \mathrm{eq} / \mathrm{kg}$ plastic emissions. Transport, $700 \mathrm{~km}$, of compunded PVC recyclate to user in Europe costs $0.1 \times 700 / 1000=0.07 € / \mathrm{kg}$ plastic and entails $134 \times 700 / 1000=94 \mathrm{gram} \mathrm{CO}_{2} \mathrm{eq} / \mathrm{kg}$ plastic emissions. Reuse of PVC recyclate bring an income of $0.09 € / \mathrm{kg}$ plastic and avoids $88 / 1320 \times 1500=100$ gram $\mathrm{CO}_{2} \mathrm{eq} / \mathrm{kg}$ plastic emissions in a market perspective and $1500 \mathrm{CO}_{2} \mathrm{eq} / \mathrm{kg}$ plastic in a 1 to 1 perspective. For external recycling, the total of needed processes minus avoided processes is a loss of $0.37 € / \mathrm{kg}$ plastic. The climate impact range between emissions of $37 \mathrm{gram} \mathrm{CO}_{2} \mathrm{eq} / \mathrm{kg}$ plastic and avoidance of $1364 \mathrm{gram} \mathrm{CO}_{2} \mathrm{eq} / \mathrm{kg}$ plastic. Bottom line: Employing hot milling instead of external recycling saves $-1.546-0.370=-1.92 € / \mathrm{kg}$ plastic (minus sign means savings/income/avoidance) and avoids emissions between $-1511-37=-1548$ gram $\mathrm{CO}_{2} \mathrm{eq} / \mathrm{kg}$ plastic and $-1512-(-1364)=-148$ gram $\mathrm{CO}_{2} \mathrm{eq} / \mathrm{kg}$ plastic.

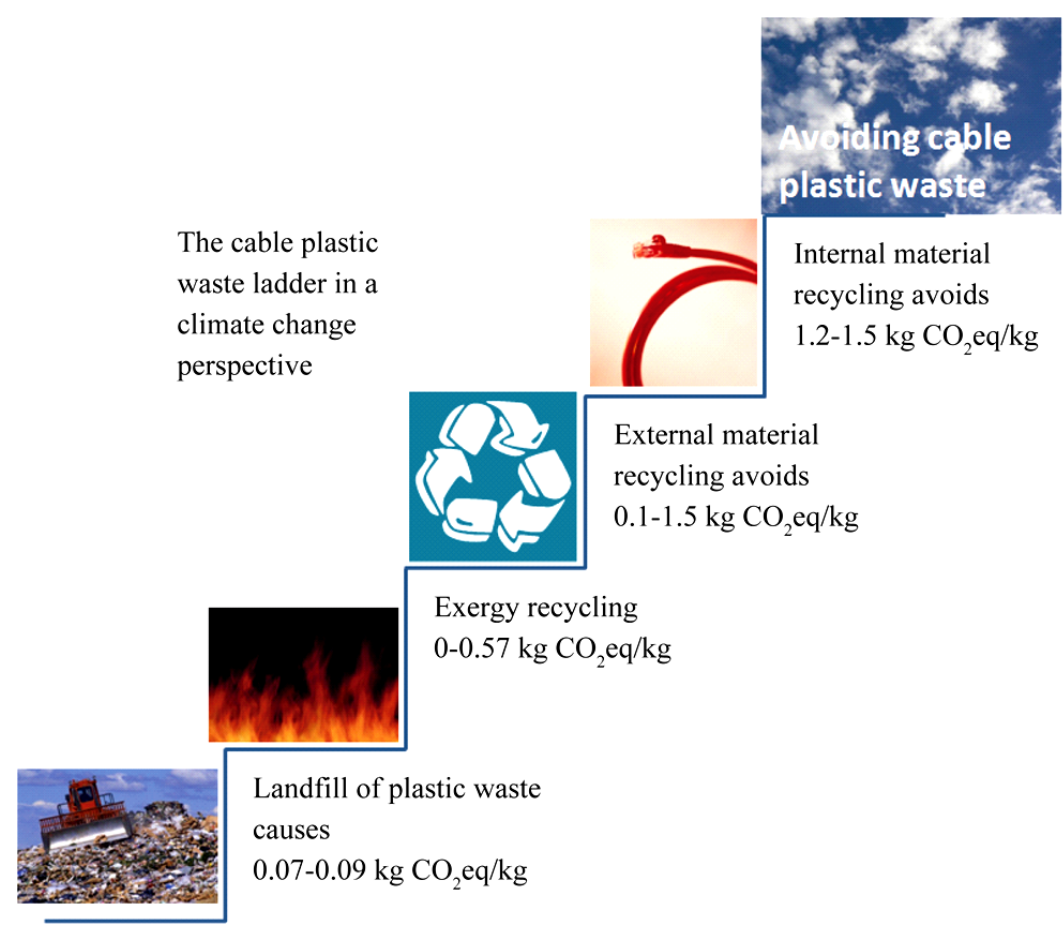

Figure 5. Potential climate change gains (per kg of plastic waste) by moving up the cable plastic waste ladder.

\subsection{Calculation Example}

Below is given an example of how to use the data in Table 1 to calculate the economics and the climate impact of a particular recycling case. It is always easier to understand the results if they are compared to one another. As a standard comparison, the current way of managing the cable plastic waste is used. The yellow boxes in 
Table 1 are summed up in the Total boxes. A clean sheet to perform other calculations is available in the underlying report [3] that also contains other calculation examples and a step-by-step procedure on how to perform them.

\section{Internal versus External Recycling}

Start and stop PVC and HFFR (halogen free flame retardant) scrap at cable extruders can be recycled directly back into extruders via hot milling of the scrap. This might need investment in mills which is not considered in this calculation. The extra work involved could often be handled by the extruder operator, thus, normally hot milling at extruders does not entail any extra work costs. It is difficult to clean the mills. Therefore, hot milling is only relevant at extruders that run the same material all the time. For increased meaning and understanding, hot milling at extruders should be compared to an alternative. A currently used alternative is to sell the hardened scrap lumps from the extruder to an external waste handler who granulates them and pass them on for mechanical recycling in a different product. It is a good idea to make a rough drawing of the processes involved in both recycling routes, see below. Avoided processes and materials are coulored yellow in Figure 6. Note that upstream processes like transport and compounding of virgin PVC is avoided by hot milling the scrap at extruders. A minus sign in Table 1 means saved or avoided $€$ or $\mathrm{CO}_{2}$ eq. It is recommended to do the calculations both with a market perspective on the avoided burdens and with a " 1 to 1 " perspective.

When the table has been completed a comparison of the bottom lines for hot milling and external recycling is done. The conclusion, in the example, is that hot milling can save more than $192000 €$ annually and avoid between 15 - 155 tonnes of $\mathrm{CO}_{2}$ eq annually. Per kg, the figures compare well with those given for internal and external material recycling in the cable plastic waste ladder in Figure 5.

\section{Discussion}

The methodology described and applied has evolved during a four year long cooperation between industrial waste management experts, the cable industry, LCA practitioners and other stakeholders. It aims to bring to the industrial decision-maker the necessary economic and environmental facts to judge the merits of competing waste management options and thus facilitate movement up the waste ladder. Some barriers and incentives related to this aim of improving waste management of plastic cable waste in particular and other waste are discussed below.

\subsection{Restricted Substances May Hinder Recycling}

It should be pointed out that the use in cables of restricted phthalates as well as restricted substances such as lead, bromide and antimony may hinder the possibilities to use recycled plastic waste from used cable. The inclusion of restricted substances in cables may also hinder all forms of external recycling of plastic waste from cable production. The subject of restricted substances in cable waste will be the focus in the Wire and Cable project run by Swerea IVF, from 2014 and onwards. The quality of various waste materials and the phasing out of hazardous waste is regulated under the Waste Framework Directive [9], where End-of-Waste criteria is developed for priority waste streams, among them plastic materials. Chemical regulations like REACH (Registration, Evaluation, Authorisation and Restriction of Chemicals) [15] and product directives like RoHS (Restriction of

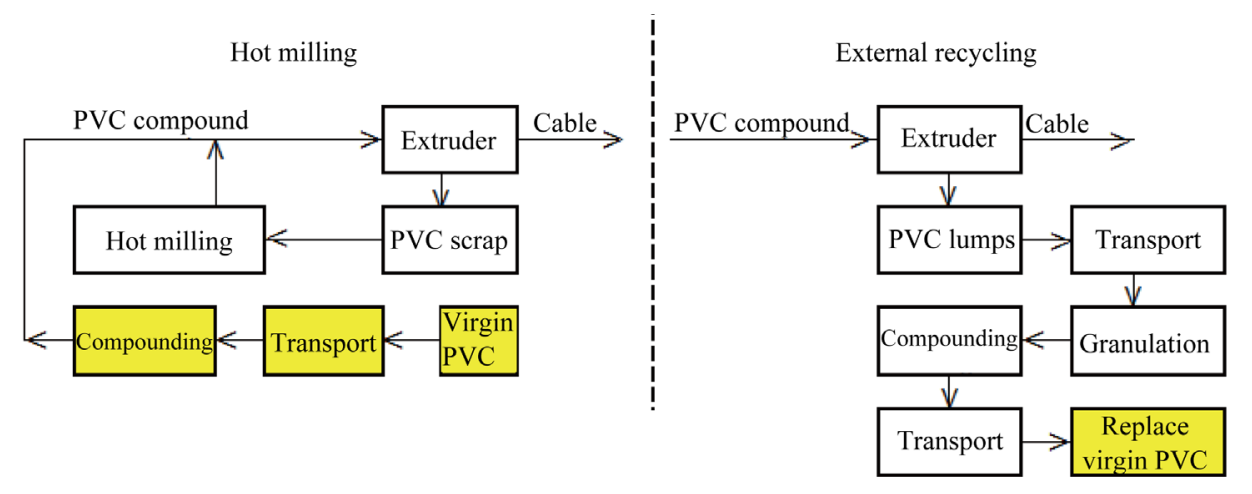

Figure 6. Hot milling of PVC scrap compared to external recycling of hardened PVC lumps. 
Hazardous Substances) [16] regulates hazardous substances in products and material used in products, regardless virgin or recycled material. This potential barrier for recycling exists for all waste materials.

\subsection{Identical Processes}

When comparing recycling routes that contain identical processes it is not necessary to include the identical processes since they equal out each other. However, when you carry out the analysis in practice it is easier to just list all the processes involved without thinking about if they equal out or not. Once included in the analysis, the processes carry some information, so you might as well leave them in. The recommendation is therefore to include also identical processes in a comparison once you have identified them. "Identical processes" that are initially forgotten need not be taken in to the calculations.

\subsection{Limitations of the System Boundary}

To be able to limit the analysis to include only the waste management processes is very advantageous since it limits drastically the amount of data needed for the analysis. One reason why this is often possible for cable waste is that when producing cables, achieving the specified product quality properties is far more important than advancing on the waste ladder. Thus, in practice, it can be assumed that the manufacturing and use of the cable will in general not be affected by any of the waste management options investigated; simply because the cable properties must remain the same. So such upstream activities can most often be excluded from the LCA. Seen from another perspective, achieving the specified product properties with the use of waste materials is probably the largest barrier to (internal) material recycling.

Downstream, the recommended use of two waste perspectives (market and 1 to 1 ), can be seen as a LCA sensitivity analysis regarding the market for the recyclate [4]. In general, the 1 to 1 approach overestimates the $\mathrm{CO}_{2}$ eq savings, while the market approach probably in most cases underestimates the $\mathrm{CO}_{2}$ eq savings. The true climate change influence most probably is somewhere in between these two extremes. It is therefore recommended to do both calculations and present the results as a span, as is done in the example calculations.

From an economic point of view the market approach must be used in order to understand the economic implications. PVC recyclate rarely sell at the same price as virgin PVC. However, when there is no price difference between the recyclate and the virgin material, then the market approach gives the same result as the 1 to 1 approach. Put another way, the market approach is only relevant when so called down-cycling of wastes occur, i.e., the waste is not reused for the same product/purpose as it was used originally or maintaining its origin quality.

\subsection{Ecodesign of Cables}

Within the Wire and Cable project, some attempts were made to elaborate guidelines for how to design cables in order to facilitate material recycling after their use. These attempts were however unsuccessful. One reason may be that in life cycle assessment of cables, as apart from LCA of cable recycling, the materials in the cable generally carry insignificant environmental impact compared to the environmental impact associated by the electricity losses during a cables life cycle [17]. In other words, the dominant environmental impact occurs during the use phase of a cable and therefore improvement work should focus on the use phase. Subsequently, less attention is put on the recycling stage. However, from a cable manufacturing point of view, the material costs are significant, and this should warrant some interest at least for improving the recyclability of production cable waste.

\subsection{The Relevance of Climate Change}

Plastsep is a technology based on sink-float separation and wet shaking table that is used to separate heavy plastics like PVC from the lighter polyolefines. Applying Plastsep to the mixed plastic waste output after granulation of used cables has proven both economically and environmentally beneficial under all conceivable circumstances [12]. It was further shown [12] that applying Plastsep not only avoided climate impact but also photochemical smog formation, eutrophication and acidification. This indicates that climate change can serve as an indicator also for these other environmental impact categories.

\subsection{Prices}

All prices should be seen as indicative. A variation of at least +- $100 \%$ should be taken for granted. Neverthe- 
less, having access to price information of some kind is very beneficial since it is never a potential climate impact avoidance alone that will make companies move up the waste ladder. Moving up the waste ladder will have to be economically beneficial (or enforced by law) otherwise it will not happen. With the information given companies can get a first idea which recycling routes are economically viable for them and which are not.

\subsection{Applicability of Methodology for Other Waste Materials}

The applicability of the applied methodology to other waste materials than plastic cable waste is discussed below for each of the five steps in the methodology.

\subsubsection{Cradle-to-Gate LCA (and LCC) for Waste Material to Recyclate}

Data relevant to the particular waste material is needed on:

- Recycling processes in the form of energy use, emissions, yield, price etc.

- Transports in the form of energy use, emissions and price.

- Primary material production in the form of energy use, emissions, price.

- Price of recyclates.

\subsubsection{Quantifying the Climate Impact for Each Step on the Waste Ladder}

To accomplish a quantified waste ladder, the particular waste material need to be well defined and the market for the waste material known, i.e. prices of recyclates. The quantified waste ladder is a pedagogic instrument to be used to rouse interest. The specific case should always be calculated with specific data.

\subsubsection{Use of Economic and Environmental Data in Parallel}

Cost data is often very sensitive. The related price information could be much easier to get access to and it is also more relevant than the cost. Fluctuation of market prices has to be considered in order to achieve long-term sustainability of waste management options.

\subsubsection{Climate Impact Presented as a Span}

It may be that some other environmental impact category than climate impact is more relevant to use or that several impact categories are needed. This should be checked for all waste materials.

As discussed above, to calculate and present the climate impact as a span, can be seen as an LCA sensitivity analysis regarding the market for the recyclate. The true climate change influence most probably is somewhere in between the top value and the lower value. If there is no price difference between the recyclate and the virgin material, then the top or high value of $\mathrm{CO}_{2}$ eq savings apply.

\subsubsection{Do-It-Yourself Calculations}

The vision of laymen doing correct life cycle calculations may be difficult to realize, but aiming there will aid in understanding and communicating the results of the life cycle calculations. This will, for example, facilitate exchange and correct understanding of LCA data between LCA practitioners. The calculations (for cable waste) can be achieved by the following steps:

1) Copy the table with all the process data and enlarge it to A3-size or larger.

2) Identify the recycling routes you want to compare. Draw simple process flow diagrams of both recycling routes, from waste to recyclate.

3) In the A3-sheet, identify and mark the (grey) processes needed to enable the recycling

4) In the A3-sheet, identify and mark the (green) products/materials and processes that are avoided/replaced by the recyclate

5) Convert data to per kg cable if necessary, see examples

6) Convert transport data according to instructions in the table

7) Examine the bottom lines of the recycling routes and calculate the difference in savings per $\mathrm{kg}$

8) Calculate the difference in savings per year for your company

\section{Conclusions}

This paper suggests cradle-to-gate life cycle assessment as a method to analyze the pros and cons of different 
cable scrap recycling options at hand. Economic and environmental data about different recycling processes and other relevant processes and materials have been collected and are presented. Cable producers could use this data and the proposed method to assess the way they deal with the cable plastic waste today and compare it with available alternatives and thus illuminate the improvement potential of recycling cable plastic waste both in an environmental and in an economic sense. The methodology suggested and applied consists of:

1) Cradle-to-gate LCA for waste material to recyclate;

2) Quantifying the climate impact for each step on the waste ladder;

3) Use of economic and climate impact data in parallel;

4) Climate impact presented as a span; and

5) Do-it-yourself calculations.

In this paper, comparisons between internal and external recycling of cable plastics show that between 1.5 $0.15 \mathrm{~kg} \mathrm{CO}$ eq can be saved per kg of plastics when moving one step up the waste ladder from external recycling to internal recycling. In economic terms, this one step up at the top of the waste ladder can increase profits by almost $2 €$ per kg plastic.

The suggested method is probably applicable also for other waste materials in society in order to move towards improved use of finite resources.

\section{References}

[1] Unger, N. and Oliver, G. (2008) Life Cycle Considerations about Optic Fibre Cable and Copper Cable Systems: A Case Study. Journal of Cleaner Production, 16, 1517-1525. http://dx.doi.org/10.1016/j.jclepro.2007.08.016

[2] JRCb (2011) Supporting Environmentally Sound Decisions for Construction and Demolition (C \& D) Waste Management.

[3] Zackrisson, M. (2013). Recycling Production Cable Waste-Environmental and Economic Aspects. Swerea IVF Report 13003, Mölndal.

[4] JRCa (2011) Supporting Environmentally Sound Decisions for Waste Management. JRC European Commission.

[5] ISO (2006) ISO 14044. Environmental Management—Life Cycle Assessment—Requirements and Guidelines.

[6] Wolf, M.-A. and Rana, P. (2012) The International Reference Life Cycle Data System. http://eplca.jrc.ec.europa.eu/uploads/2014/02/JRC-Reference-Report-ILCD-Handbook-Towards-more-sustainable-prod uction-and-consumption-for-a-resource-efficient-Europe.pdf

[7] Björklund, A. and Finnveden, G. (2005) Recycling Revisited-Life Cycle Comparisons of Global Warming Impact and Total Energy Use of Waste Management Strategies. Resources, Conservation and Recycling, 44, 309-317. http://dx.doi.org/10.1016/j.resconrec.2004.12.002

[8] Zackrisson, M., Cristina, R., Kim, C. and Anna, J. (2008) Stepwise Environmental Product Declarations: Ten SME Case Studies. Journal of Cleaner Production, 16, 1872-1886. http://dx.doi.org/10.1016/j.jclepro.2008.01.001

[9] European Commission (2008) Directive 2008/98/EC of the European Parliament and of the Council of 19 November 2008 on Waste and Repealing Certain Directives.

[10] Zackrisson, M. (2012) Life Cycle Assessment of Cable Recycling. Part I: Plastsep Compared to State of the Art. Swerea IVF Report, Swerea IVF AB, Mölndal.

[11] Ecoinvent (2010) The Life Cycle Inventory Data Version 2.2. Ecoinvent Database.

[12] IPCC (2007) Climate Change 2007 the Physical Science Basis. http://www.ipcc.ch/publications_and_data/ar4/wg1/en/ch2s2-10-2.html\#table-2-14

[13] IEC (2004) Dependability Management_Part 3-3: Application Guide—Life Cycle Costing. IEC 60300-3-3.

[14] AMI (2012) AMI's Guide to the Cable Extrusion Industry in Europe (Edition 6). www.amiplastics.com

[15] European Commission (2006) REGULATION (EC) No 1907/2006 of the European Parliament and of the Council of 18 December 2006 Concerning the Registration, Evaluation, Authorisation and Restriction of Chemicals (REACH).

[16] European Commission (2011) DIRECTIVE 2011/65/EU of the European Parliament and of the Council of 8 June 2011 on the Restriction of the Use of Certain Hazardous Substances in Electrical and Electronic Equipment.

[17] Jones, C.I. and Marcelle, C.M. (2010) Life-Cycle Assessment of 11 kV Electrical Overhead Lines and Underground Cables. Journal of Cleaner Production, 18, 1464-1477. http://dx.doi.org/10.1016/j.jclepro.2010.05.008 